\title{
INCREASING VOCABULARY MASTERY OF THE FIRST YEAR STUDENTS OF SMP NEGERI 3 PAMBOANG THROUGH CONCEPT MAPPING STRATEGY
}

\author{
Nurfitri $^{1}$, Abdul Haris Sunubi ${ }^{2}$ \\ Institut Agama Islam Negeri (IAIN) Parepare ${ }^{123}$ \\ nurfitri.majene@gmail.com ${ }^{1}$
}

\begin{abstract}
This study is to see increasing vocabulary mastery of the first-year students of SMP Negeri 3 Pamboang through concept mapping strategy. The problems in this research are using concept mapping strategy able to increase students' vocabulary in the first-year students of SMP Negeri 3 Pamboang. This study aimed to know the students' responses toward concept mapping strategy in increasing vocabulary and to find out whether there is a significant increase of students' vocabulary achievement as a result of using concept mapping strategy. This study employed a quantitative research design which is a case study using preexperimental design which applied (one group pre-test and post-test design). The study found out that there was an improvement of the students' vocabulary mastery after giving the learning process by using concept mapping strategy. It can be concluded that the students'vocabulary mastery is significantly better after getting the treatment. This study also provides a set of recommendation to avoid overlapped researches in education technology.
\end{abstract}

Keywords: Vocabulary Mastery, Concept Mapping, Strategy.

\section{Introduction}

English is the language is essential to the field of education. The teaching of English to students is purposed to develop the four language skill of speaking, listening, reading, and writing. It means that the students are expected to develop these language skills through their activities in the class. To support the development of the four language skills, the learning of language components is needed. The language components are consist of pronunciation, grammar, and vocabulary.

Vocabulary is one of the language components that have an important role in the development of the language skills because for large majority of learners, the ultimate goal of studying is able to communicate. The importance of vocabulary is demonstrated daily in and out the school. In classroom, the achieving students possess the most sufficient vocabulary (MofarehAlqahtani, 2015).For example the students cannot read well if they do 
not have vocabulary because they would be difficult to translate it. But in increasing students vocabulary is not easy. Some of students' opinions in SMP Negeri 3 Pamboang said that learn English is difficult subject especially in remember the word or vocabulary. So that the students are difficult to speak in English because the lack of mastery of vocabulary and more teachers provide material vocabulary simply by having students look for vocabulary in the dictionary then asks students to memorize. Because of that, they are lack of motivation to study English and they need high motivation to learn English.

In the implementation of English learning process, the researcher often find the students in SMP Negeri 3 Pamboang, the school where the researcher would research difficulties in achieving a basic competence. This was because the mastery of English vocabulary of students was not sufficient, so it was very disturbing achievement of competencies as listed in the curriculum. They often had difficulty understanding the meaning of a word because their vocabulary comprehension is relatively inadequate so that the process of achieving a basic competence will run longer.

If the students have difficulty in understanding the meaning of a word during the learning process then the teacher finally forced to give a shortcut on them by: 1) Asking students search for the meaning of the word on the dictionary. 2) Directly notify the meaning of the word. Although such a way if too often used is not good for students because: 1) only some students have dictionaries. 2) The student becomes dependent on the dictionary not on the understanding of the word context. 3) Students often wait on the meaning of the word that comes from the teacher.

To change the mindset of students that learning English is difficult, the teachers have to creative in teaching, selecting approaches and strategies, so that students would be more active in the learning process of English in the classroom. There were many strategies that can be used to improve the mastery of English vocabulary.

Knowing the problems above, this research applied a concept mapping strategy as one of the strategy to help the students in generating and developing their ideas and to increase their vocabularies. Concept mapping is a diagram showing the relationship among concepts. It is a graphical tool for organizing and representing knowledge (SararinduBera, RamakantaMohalik, 2016). 
Finally, this strategy was expected to improve the ability of students in mastering the vocabulary. Based on the explanation above, the researcher interested in conducting research with the title "Increasing Vocabulary Mastery of The First Year Students of SMP Negeri 3 Pamboang Through Concept Mapping Strategy.

According to backgroud above, the research question of this research can be stated as follow: "Is using concept mapping strategy able to increase students' vocabulary at the first year students of SMP Negeri 3 Pamboang?" The objective of this study is: "To find out whether there is a significant increasing of students' vocabulary achievement as a result of using concept mapping strategy." Before giving the treatment there are some problems in vocabulary mastery, one of the problem which made the students lack in vocabulary mastery caused by strategy of the teacher used in learning process is always monotonous. The teacher rarely used strategy or game in learning process. So, many vocabularies were not familiar to the students because of it. After giving treatment "The concept mapping strategy" had impact in increasing the students vocabulary. As a fact, based on the finding, most students had an excellent score in post-test. It meant that, the treatment was success in increasing the students' vocabulary mastery. The researcher used this strategy by combined with practiced. Concept mapping strategy made learning process become interest because the researcher combined with practice and game at the time.It can be concluded that the students'vocabulary mastery is significant better after getting the treatment.

There are some significances in this research, as follows: For the studentsBy this experiencing implementation of teaching the concept mapping strategy visually as teaching method on student's mastering of vocabulary. Therefore, the students can use the vocabulary they have learned in the communication.For the Teachers, the teacher become creative person and always up-date the information and selects appropriate method to make teaching-learning process effective.For the researchers, this researcher expected to give a new knowledge of the further of researcher to do the better research of teaching and learning cases, and to solve the students' vocabulary problems, and also the teachers that have the similar problem with this researcher. 


\section{Method}

This research used pre-experimental design with pre-test and post-test design. The students would be given pre-test, treatment and post-test. It purposed to know whether using concept mapping can increase the students' vocabulary.

The location of the research took a place at SMP Negeri 3 PamboangKabupatenMajene. The researcher used the quantitative research that have several times to collect and analyze data. So, the researcher used more than one month for collecting the data.

The population of the research was the first year students of SMP Negeri 3 Pamboang academic year 2017/2018. Consist of VII $\mathrm{A}=21$, VII B $=20$, and VII $\mathrm{C}=21$. The totals of population are 62 students.

The sample took by random sampling. The researcher took the class VII B which is consistof 20 students as the sample of this research.

The collect of the data, the researcher used a vocabulary test as the instrument. The test applied for pre-test and post-test. The pre-test intended to know the student's prior of vocabulary before giving the treatment, while the post-test will intend to know the students' vocabulary after giving the treatment visually.

The procedures of collecting data as follows: before giving the treatment, pre-test administrated the students by giving them some vocabulary test. After giving the pre-test the next time the researcher will give the students treatment.After giving a pre-test, the researcher gave treatment to the students in the classroom. The procedure of treatment that researcher presented and introduced the materials to the class and explained what the students have to do. After that the researcher gave the student and activity through visual method.After giving the treatment, the researcher gave the students post-test to find the result of the treatment to measure students' vocabulary through concept mapping strategy; the researcher gave some test vocabularies.

The data would be collected through the test that have been analyzed by using quantitative analysis employed statically calculation. 


\section{Result}

The findings of this research deal with the classification of the students' pre-test and post-test. A pre-test was given before treatment to know the students' vocabulary mastery, while post-test was given after treatment through concept mapping strategy and the result of the post-test of this research can answer the question of this research that aims to find out through concept mapping strategy to increase the students' vocabulary mastery of junior high school 3 Pamboang.

The students' score in pre-test

The pre-test had done before giving concept mapping strategy. It was conducted on Monday, March 26th, 2018. The students were given a pre-test. The researcher found out the result of the students pre-test based on the scoring of vocabulary before giving a treatment through concept mapping strategy which were analyzed and resulted in the information as shown in the following table are to find out the mean score.

Table.1The students' score in pre-test

\begin{tabular}{ccccccc}
\hline \multirow{2}{*}{ No } & \multirow{2}{*}{ Students } & Score & \multicolumn{2}{c}{$\begin{array}{c}\text { Pre-Test of the } \\
\text { Students }\left(X_{1}\right)\end{array}$} & \multirow{2}{*}{ XLASSIFICATION } \\
\cline { 3 - 6 } & & & Max Score & Score $X_{1}$ & & \\
\hline 1 & S1 & 51 & 4 & 2.04 & 4.1616 & Enough \\
\hline 2 & S2 & 48 & 4 & 1.92 & 3.6864 & Enough \\
\hline 3 & S3 & 36 & 4 & 1.44 & 2.0736 & Poor \\
\hline 4 & S4 & 60 & 4 & 2.4 & 5.76 & Enough \\
\hline 5 & S5 & 43 & 4 & 1.72 & 2.9584 & Enough \\
\hline 6 & S6 & 43 & 4 & 1.72 & 2.9584 & Enough \\
\hline 7 & S7 & 36 & 4 & 1.44 & 2.0736 & Poor \\
\hline 8 & S8 & 67 & 4 & 2.68 & 7.1824 & Good \\
\hline 9 & S9 & 40 & 4 & 1.6 & 2.56 & Enough \\
\hline 10 & S10 & 47 & 4 & 1.88 & 3.5344 & Enough \\
\hline 11 & S11 & 50 & 4 & 2 & 4 & Enough \\
\hline 12 & S12 & 50 & 4 & 2 & 4 & Enough \\
\hline 13 & S13 & 38 & 4 & 1.52 & 2.3104 & Enough \\
\hline 14 & S14 & 46 & 4 & 1.84 & 3.3856 & Enough \\
\hline 15 & S15 & 61 & 4 & 2.44 & 5.9536 & Enough \\
\hline 16 & S16 & 47 & 4 & 1.88 & 3.5344 & Enough \\
\hline 17 & S17 & 36 & 4 & 1.44 & 2.0736 & Poor \\
\hline 18 & S18 & 36 & 4 & 1.44 & 2.0736 & Poor \\
\hline 19 & S19 & 53 & 4 & 2.12 & 4.4944 & Enough \\
\hline & & & & & & \\
\hline
\end{tabular}


Inspiring: English Education Journal

Volume I No 2 September2미맘

\begin{tabular}{cc|c|cccc}
20 & S20 & 56 & 4 & 2.24 & 5.0176 & Enough \\
\hline Total & $\sum \mathrm{X}=944$ & & $\sum \mathrm{X}=37.76$ & $\sum \mathrm{X}^{2}=73.792$ & \\
\hline
\end{tabular}

(Data' Source: the students' Score in pre-test)

The table above showed that the result of students' vocabulary mastery score before applying the concept mapping strategy. There were one student got good score and fifteen students got enough score and four students got poor. The total score in pre-test was 37.76 . It had shown that, the students' ability in vocabulary pre -test was low, because most of the students got enough and poor score.

Based on the result of the pre-test, the data showed that the mean score of the pretest is 1.88 From that analyzing. It could be seen that almost of the 20 students' ability in vocabulary was still low. After determining the mean score (X1) of pre-test was 37.76 and standard deviation of the pre-test was 0.36 . It could be seen that the students' vocabulary mastery were in low category.

The students score in post-test

Meanwhile, the students' score in posttest would be presented to find out the mean score and the standard deviation.

Table 2.The students' score in post-test

\begin{tabular}{ccc|cccc}
\hline \multirow{2}{*}{ No } & \multirow{2}{*}{ Students } & Score & \multicolumn{4}{|c}{ Post-Test of the Students $\left(\mathbf{X}_{\mathbf{2}}\right)$} \\
\cline { 3 - 7 } & & & Max Score & Score $\mathbf{X}_{\mathbf{2}}$ & $\mathbf{X}_{\mathbf{2}}{ }^{\mathbf{2}}$ & Classification \\
\hline 1 & S1 & 90 & 4 & 3.6 & 12.96 & Excellent \\
\hline 2 & S2 & 79 & 4 & 3.16 & 9.9856 & Good \\
\hline 3 & S3 & 77 & 4 & 3.08 & 9.4864 & Good \\
\hline 4 & S4 & 92 & 4 & 3.68 & 13.5424 & Excellent \\
\hline 5 & S5 & 90 & 4 & 3.6 & 12.96 & Excellent \\
\hline 6 & S6 & 81 & 4 & 3.24 & 10.4976 & Good \\
\hline 7 & S7 & 70 & 4 & 2.8 & 7.84 & Good \\
\hline 8 & S8 & 98 & 4 & 3.92 & 15.3664 & Excellent \\
\hline 9 & S9 & 73 & 4 & 2.92 & 8.5264 & Good \\
\hline 10 & S10 & 82 & 4 & 3.28 & 10.7584 & Good \\
\hline 11 & S11 & 90 & 4 & 3.6 & 12.96 & Excellent \\
\hline 12 & S12 & 83 & 4 & 3.32 & 11.0224 & Good \\
\hline 13 & S13 & 79 & 4 & 3.16 & 9.9856 & Good \\
\hline 14 & S14 & 86 & 4 & 3.44 & 11.8336 & Good \\
\hline 15 & S15 & 92 & 4 & 3.68 & 13.5424 & Excellent \\
\hline 16 & S16 & 87 & 4 & 3.48 & 12.1104 & Good \\
\hline
\end{tabular}




\begin{tabular}{lcccccc}
17 & S17 & 60 & 4 & 2.4 & 5.76 & Enough \\
\hline 18 & S18 & 65 & 4 & 2.6 & 6.76 & Good \\
\hline 19 & S19 & 83 & 4 & 3.32 & 11.0224 & Good \\
\hline 20 & S20 & 81 & 4 & 3.24 & 10.4976 & Good \\
\hline \multirow{2}{*}{ Total } & & $\sum \mathbf{X = 1 6 3 8}$ & & $\begin{array}{c}\sum \mathbf{X}_{\mathbf{2}}=\mathbf{6 5} . \\
\mathbf{5 2}\end{array}$ & $\begin{array}{c}\sum \mathbf{X}_{\mathbf{2}}^{2}=\mathbf{2 1} \\
\mathbf{7 . 4 1 7 6}\end{array}$ & \\
\hline
\end{tabular}

(Data' source: the students' score in post test)

The table above showed that there were an increasing of students' score after giving treatment through concept mapping strategy. There were six students got excellent score, thirteen students got good score, one student got enough score, and no one student got poor score. It means that the students' vocabulary ability had improved through concept mapping strategy. The total score in posttest was 65.52.

Based on the result of the post-test. The data showed that the mean score of the post-test was 3.27. From that analyzing, it could be seen that almost of the 20 students' vocabulary was excellent and good score.

The result of the pre-test and post-test were presented in the following:

Table 3.the mean score and standard deviation of pre-test and post-test

\begin{tabular}{|c|c|c|}
\hline Test & Mean Score & Standard Deviation (SD) \\
\hline Pre-test & 1.88 & 0.36 \\
\hline Post-test & 3.27 & 0.38 \\
\hline
\end{tabular}

(Data source: the mean score and standard deviation of pre-test and post test)

The data in table 3 showed that the mean score of the pre-test was 1.88 (X1) while the mean score of the post-test increased 3.27 (X2). The standard deviation of pre-test was 0.36 while the standard deviation of the posttest was 0.38 . As a result of the item, students' vocabulary mastery had increased after doing the learning process that used the concept mapping strategy.

The rate percentage of the frequency of the pre-test and post-test

The following table showed the percentage of the frequency in pre-test and posttest.

Table 4.the rate percentage of the frequency of the pre-test and post-test

\begin{tabular}{|c|c|c|c|c|c|c|}
\hline \multirow[t]{2}{*}{ No } & \multirow[t]{2}{*}{ Classification } & \multirow[t]{2}{*}{ Score } & \multicolumn{2}{|c|}{ Frequency } & \multicolumn{2}{|c|}{ Percentage } \\
\hline & & & Pre-test & Post-test & Pre-test & Post-test \\
\hline 1. & Excellent & $\begin{array}{l}3.85-4.00 \\
3.51-3.83\end{array}$ & 0 & 6 & $0 \%$ & $30 \%$ \\
\hline
\end{tabular}


Inspiring: English Education Journal

Volume I No 2 September2018

\begin{tabular}{|c|c|c|c|c|c|c|}
\hline 2. & Good & $\begin{array}{l}3.18-3.50 \\
2.85-3.17 \\
2.51-2.84 \\
\end{array}$ & 1 & 13 & $5 \%$ & $65 \%$ \\
\hline 3. & Enough & $\begin{array}{c}2.18-2.50 \\
1.85-2.17 \\
1.51-1.84 \\
\end{array}$ & 15 & 1 & $75 \%$ & $5 \%$ \\
\hline 4. & Poor & $\begin{array}{l}1.18-1.50 \\
1.00-1.17 \\
\end{array}$ & 4 & 0 & $20 \%$ & $0 \%$ \\
\hline & Total & & 20 & 20 & $100 \%$ & $100 \%$ \\
\hline
\end{tabular}

(Data source: the rate percentage of thefrequency of the pre-test and post test)

The data of the table above indicated that rate percentage of the pre-test one $(5 \%)$

student got good score, fifteen (75\%) students got enough score, and four (20\%) students got poor score while the rate percentage of the post-test, six (30\%) students got excellent score, thirteen (65\%) students got good score, and one $(5 \%)$ students got enough score. The percentage in post-test that students got excellent score was higher than percentage in pretest. It showed that implementation of concept mapping strategy was able to increase the students’ vocabulary masteryat SMP Negeri 3 Pamboang.

t-test value

The following is the table to find out the difference of the mean score between pretest and post-test.

Table 5.The worksheet of the calculation of the score on pre-test and post-test on the students' vocabulary mastery

\begin{tabular}{ccccccc}
\hline $\mathbf{N o}$ & $\mathbf{X}_{\mathbf{1}}$ & $\mathbf{X}_{\mathbf{2}}$ & $\mathbf{( \mathbf { X } _ { \mathbf { 1 } } ) ^ { \mathbf { 2 } }}$ & $\mathbf{( \mathbf { X } _ { \mathbf { 2 } } ) ^ { \mathbf { 2 } }}$ & $\mathbf{D}\left(\mathbf{X}_{\mathbf{2}}-\mathbf{X}_{\mathbf{2}}\right)$ & $\left(\mathbf{X}_{\mathbf{2}}-\mathbf{X}_{\mathbf{1}}\right) \mathbf{2}$ \\
\hline 1 & 2.04 & 3.6 & 4.1616 & 12.96 & 1.56 & 2.4336 \\
\hline 2 & 1.92 & 3.16 & 3.6864 & 9.9856 & 1.24 & 1.5376 \\
\hline 3 & 1.44 & 3.08 & 2.0736 & 9.4864 & 1.64 & 2.6896 \\
\hline 4 & 2.4 & 3.68 & 5.76 & 13.5424 & 1.28 & 1.6384 \\
\hline 5 & 1.72 & 3.6 & 2.9584 & 12.96 & 1.88 & 3.5344 \\
\hline 6 & 1.72 & 3.24 & 2.9584 & 10.4976 & 1.52 & 2.3104 \\
\hline 7 & 1.44 & 2.8 & 2.0736 & 7.84 & 1.36 & 1.8496 \\
\hline 8 & 2.68 & 3.92 & 7.1824 & 15.3664 & 1.24 & 1.5376 \\
\hline 9 & 1.6 & 2.92 & 2.56 & 8.5264 & 1.32 & 1.7424 \\
\hline 10 & 1.88 & 3.28 & 3.5344 & 10.7584 & 1.4 & 1.96 \\
\hline 11 & 2 & 3.6 & 4 & 12.96 & 1.6 & 2.56 \\
\hline 12 & 2 & 3.32 & 4 & 11.0224 & 1.32 & 1.7424 \\
\hline 13 & 1.52 & 3.16 & 2.3104 & 9.9856 & 1.64 & 2.6896 \\
\hline 14 & 1.84 & 3.44 & 3.3856 & 11.8336 & 1.6 & 2.56 \\
\hline 15 & 2.44 & 3.68 & 5.9536 & 13.5424 & 1.24 & 1.5376 \\
\hline
\end{tabular}


Inspiring: English Education Journal

Volume I No 2 September2018

\begin{tabular}{ccccccc}
\hline 16 & 1.88 & 3.48 & 3.5344 & 12.1104 & 1.6 & 2.56 \\
\hline 17 & 1.44 & 2.4 & 2.0736 & 5.76 & 0.96 & 0.9216 \\
\hline 18 & 1.44 & 2.6 & 2.0736 & 6.76 & 1.16 & 1.3456 \\
\hline 19 & 2.12 & 3.32 & 4.4944 & 11.0224 & 1.2 & 1.44 \\
\hline 20 & 2.24 & 3.24 & 5.0176 & 10.4976 & 1 & 1 \\
\hline Total & $\mathbf{3 7 . 7 6}$ & $\mathbf{6 5 . 5 2}$ & $\mathbf{7 3 . 7 9 2}$ & $\mathbf{2 1 7 . 4 1 7 6}$ & $\mathbf{2 7 . 7 6}$ & $\mathbf{3 9 . 5 9 0 4}$ \\
\hline
\end{tabular}

In the other to see the students' score, the following is t-test was statistically applied:

To find out $\mathrm{D}$ used the formula as follow:

$\mathrm{D}=\frac{\sum D}{\mathrm{~N}}=\frac{27,76}{20}=1.388$

The calculation the t-test value

$$
\begin{aligned}
& \mathrm{t}=\frac{\mathrm{D}}{\sqrt{\frac{\sum \mathrm{D}^{2}-\frac{(\mathrm{N} \mathrm{D})^{2}}{\mathrm{~N}}}{\mathrm{~N}(\mathrm{~N}-1)}}=\frac{1,388}{\sqrt{\frac{39,5904-\frac{27,76^{2}}{20}}{20(20-1)}}}} \\
& \mathrm{t}=\frac{1 l 388}{\sqrt{\frac{39,5904-38,53088}{380}}}=\frac{1.388}{\sqrt{0.0027}} \\
& \mathrm{t}=\frac{1.388}{0.051}=27.22
\end{aligned}
$$

Thus, the t-test value is 27.22

This research used pre-experimental design with pre-test and post-test design. The data below showed that the value of t-test was greater than t-table value. In indicated that there was a significant difference between the result students' pre-test and post test.

Table 6. the test of significant

\begin{tabular}{ccc}
\hline Variable & T-test & T-table value \\
\hline Pre-test - post-test & 27.22 & 1.729 \\
\hline
\end{tabular}

Hypothesis Testing

To find out degree of freedom (df) the researcher used the following formula:

$$
\begin{aligned}
D f & =N-1 \\
& =20-1 \\
& =19
\end{aligned}
$$

For the level, significant $(\alpha) 5 \%$ and $\mathrm{df}=19$, and the value of the table is 1.729 , while the value of $t$-test 27.22 . It means that the $t$-test value is greater than $t$-table $(27.22 \geq$ 
1.729). Thus, it can be concluded the students' vocabulary mastery through concept mapping strategy is significant better after getting the treatment. So, the null hypothesis $\left(\mathrm{H}_{0}\right)$ is rejected and the alternative hypothesis $\left(\mathrm{H}_{\mathrm{a}}\right)$ is accepted.

\section{Discussion}

To know the improvement of students' vocabulary through concept mapping strategy, the researcher calculated the mean score students' vocabulary was indicated from two tests namely pre-test and post-test. The mean score in pre-test before treatment was 0.36 and the mean score of post-test was 0.38 after treatment.

By looking at the test finding, from the data provided in classification table based on the vocabulary, clearly to see that one (5\%) student got good score, fifteen (75\%) students got enough score, and four (20\%) students got poor score in the pre-test, while in the posttest, six (30\%) students got excellent score, thirteen (65\%) students got good score, and one (5\%) student got enough score. From the result the researcher concluded that the students' vocabulary mastery from poor to excellent classification.

In addition, to know what was the hypothesis received between null hypothesis $\left(\mathrm{H}_{0}\right)$ and alternative hypothesis $\left(\mathrm{H}_{\mathrm{a}}\right)$, the researcher used t-test to calculating result showed that on the t-test value 27.22 was greater than $t$-table value 1.729 table $(27,22 \geq 1.729)$ with degree of freedom (df) 19. It means alternative hypothesis $\left(\mathrm{H}_{\mathrm{a}}\right)$ was concluded that the concept mapping strategy was able to increase the students' vocabulary mastery at the first year of SMP Negeri 3 Pamboang. This hypothesis was accepted while the null hypothesis $\left(\mathrm{H}_{0}\right)$ was rejected.

In the preface study that the researcher did at SMP Negeri 3 Pamboang it was found through the observation that the teachers' method in teaching vocabulary was mainly using memorizing method, the students seldom use media, strategy, and also confirmed by the students that strategy in the class is monotonous so that the students got bored.The teacher rarely used strategy or game in learning process. So, many vocabularies were not familiar to the students because of it. As consequences the students lack in vocabulary mastery.

Based on the findings above, the researcher concluded that there was an increasing of using concept mapping strategy in vocabulary mastery of SMP Negeri 3 Pamboang. The 
concept mapping strategy had impact in increasing the students' vocabulary. As a fact, based on the finding, most students had an excellent score in post-test. It meant that, the treatment was success in increasing the students' vocabulary mastery. The researcher used this strategy learning process become interest because the researcher combines with practice and game at the time.

There were four meetings for doing the treatment of this research. At the first, before giving the treatment, the students did the pre-test it purposed to know students' ability in vocabulary mastery before getting the treatment. The step of this test was the researcher started to do the brainstorming to take the students attention and made the students interest to do the next instruction of the researcher. The researcher asked some vocabularies to the students before giving test of pre-test. In test the researcher directly used concept mapping form but without asked the students that the test was their answer was one of strategy. It purposed to know the students' ability in vocabulary mastery before getting the treatment. In this case, the researcher checked the students' work at home. The researcher gave some correction on the students' paper by insert a missing word, and delete the word that was not connect with the main idea of the test.

In the first meeting on Monday, March 26th, 2018, the researcher gave motivation to the students about the easy to study English then the researcher gave back the students' paper that has been any corrections in it. After that, the researcher asked the students about concept mapping strategy and how to make it. The students were very enthusiastic in learning because the teacher never used concept mapping strategy in teaching vocabulary. The researcher began to guide the students to understand the process of concept mapping strategy. Firstly, the researcher gave one of mind idea for example food and fruits. Secondly, the researcher gave time for the students to look at the vocabulary that had related to food and fruits and wrote in the paper.

On Thursday, March 29th, 2018 was the second meeting, the researcher gave some lists of vocabulary from some mind ideas. It made the students easy to understand and memorize. In this learning process, the researcher has prepared some Media to make a concept mapping. It was put on the whiteboard after that the researcher gave students' chance to mention one of the mental ideas. In the next step, one by one the students were 
asked to look the word every student had to have five words that had related to mind idea by a researcher. Directly the students put the words on a whiteboard that had prepared and the students made a concept mapping especially spider concept mapping.

The third meeting on Wednesday, April 11th, 2018, the researcher gave a test in the form of concept mapping. It purposed to know that students had progressed in vocabulary mastery or not. In this meeting, the students had been divided into four groups to make the researcher easy to do the strategy. The researcher provided different mind idea in every group. After that, the students looked the word that had related to mind idea. After the students had finished, every group explained the result of their discussion in front of another group. After that, the researcher gave some lists of vocabulary from some mind ideas. It made the students easy to understand and memorize

On Friday, April 13th, 2018 was the fourth meeting. Before beginning this meeting, the researcher gave a test again to students with different ideas. In this meeting was different from the previous meeting. The researcher used concept mapping strategy combined with the game so that the students did not get bored in the class, the game used by researcher had a relationship with the concept mapping, this meeting was done outside the classroom so that the students can freely accept the material in a relaxed and quickly absorbed.

In the last, the researcher gave a post-test on Monday, April 9th, 2018. Before that, the researcher did brainstorming first to take the students' focusing and their attention. The students answered the question based on their knowledge after treatment. In this, the researcher did not give back the students' paper again. Its purpose to know whether this treatment had increased or not.

From the first meeting until the last meeting, the implementation of the concept mapping strategy changed classroom situation in class and the learning process. The students were more motivated and they enjoyed in class, the students were more active to ask about the lesson what they did not understand, students gave more responses when the researcher asked to do the task in front of the classroom, and students were pleased with the situation. As a conclusion, the concept mapping strategy had to increase the students' vocabulary mastery. 


\section{Conclusion}

Based on the result of data analysis and the discussion, the result showed a positive impact on the students' vocabulary ability and class situation. This study is categorized preexperiment research design, the objective in this study is to find out whether concept mapping strategy was able or not to increase students' vocabulary mastery. Therefore, the researcher concluded that there is a significant difference in the students' vocabulary mastery before and after treatment. The following are the description of the conclusion based on the problem statement of this research: T-test result in which the value of t-test was 27.22. It was greater than t-table was 1.729 at the level of significance 0.05 and degree of freedom (df) was 19. The mean score of pre-test (1.88), standard deviation (0.36), and the mean score of post-test (3.27) and the standard deviation (0.38)

Based on the description of the result above, it can be proved by looking at the mean score of the students' writing test in pre-test and post-test. The mean score of pre-test (1.88) is lower than the mean score of post-test $(3,27,9)$. Then, the t-test $(27.22)$ was greater than the t-table (1.729). it means that the null hypothesis (H0) was rejected and the alternative hypothesis (Ha) was accepted.

Based on the research, the researcher gives some suggestions as follow: In teaching vocabulary, the teacher is hoped more creative and has good feedback in teaching her students in order to maximize teaching-learning process and does not make the students be bored. The teacher should be active in giving feedback to involve the students in the teaching-learning process. The students should be more active and not afraid of making mistakes during the teaching-learning process. The students should practice and measure their vocabulary in English, discussing with their friends if they have difficulty in vocabulary and enjoy the vocabulary class. Concept mapping strategy can be applied in the English teaching-learning process, particularly the attempt of improving the students' vocabulary mastery.

\section{References}

Alqahtani,Mofareh. 2015. "The Importance of Vocabulary in Language Learning and How ToBeTaught. 'International Journal of Teaching and Education, Vol III, No 3. 
Andy. 2012. Let's Talk English. Bekasi: Global Synergy Maxima

Arikunto, Suharsimin.2009. Dasar-dasarEvaluasiPendidikan. Jakarta: BumiAksara.

Asan,Askin. 2007. " Concept Mapping in Science Class: A case study of fifth grade students."Educational Technology \& Society, Vol. 10, No.1.

Bera, SararindudanRamakantaMohalik. 2016. "Effectiviness of Concept Mapping Strategy on Cognitive Processes in Science at Secondary Level."European Academic Research, Vol. IV, Issue 4.

Gay L.R. 1976. Educational Research, competencies for analysis and aplication second edition. Columbus: Charles E. Merril Publishing Company A Bell \& Howell Company.

Gay, L.R, Geoffrey E Mills, and Peter Airasian. 2012. Educational Research Competencies for Analysis and Application Tenth Edition. USA: PEARSON

Hanson, Susan and Jennifer F.M Padua.Teaching Vocabulary Explicitly ( U.S:Pacific Resources fo $r$ Education and Learning.

Miki Tomita,YueYinJimVarides, and Maria Araceli Ruiz-Primo. 2005. "Using concept maps in the science classroom." Science scope, vol 28, no.8.

Nation, I.S.P. 1990.Teaching \& Learning Vocabulay.United Stated of America: Heinle\&Heinle Publishers.

Oxford. 2008. Oxford Leaners's pocket dictionary. New York : Oxford University Press.

Paul Nation."Teaching Vocabulary." (Asean EFL Journal)

Qi Pan. 2011. "Vocabulary Teaching in English Language Teaching,"(Theory and Practice in Language Studies, Vol.1, No.11.

Saepuddin, et al., eds.2013.PedomanPenulisanKaryallmiah.Parepare: SekolahTinggi Agama Islam Negeri (STAIN) Parepare

Soepeno, Bambang. 2002. StatistikTerapanDalamPenelitianIlmu-ilmuSosial\&Pendidikan. Jakarta: PT.RINEKA CIPTA.

Sudijon, Anas.2006.Pengantar StatistikPendidikanJakarta: Raja GrafindoPersada 
Inspiring: English Education Journal

Volume I No 2 September2018 